University of Nebraska - Lincoln

DigitalCommons@University of Nebraska - Lincoln

\title{
Comparative Toxicity of Aqueous Solutions of Boric Acid and Polybor 3 to House Flies (Diptera: Muscidae)
}

Jerome Hogsette

USDA-ARS, Jerry.Hogsette@ars.usda.gov

Philip Koehler

USDA-ARS

Follow this and additional works at: https://digitalcommons.unl.edu/usdaarsfacpub

Part of the Agricultural Science Commons

Hogsette, Jerome and Koehler, Philip, "Comparative Toxicity of Aqueous Solutions of Boric Acid and Polybor 3 to House Flies (Diptera: Muscidae)" (1992). Publications from USDA-ARS / UNL Faculty. 1004. https://digitalcommons.unl.edu/usdaarsfacpub/1004

This Article is brought to you for free and open access by the U.S. Department of Agriculture: Agricultural Research Service, Lincoln, Nebraska at DigitalCommons@University of Nebraska - Lincoln. It has been accepted for inclusion in Publications from USDA-ARS / UNL Faculty by an authorized administrator of DigitalCommons@University of Nebraska - Lincoln. 


\title{
Comparative Toxicity of Aqueous Solutions of Boric Acid and Polybor 3 to House Flies (Diptera: Muscidae)
}

\author{
JEROME A. HOGSETTE AND PHILIP G. KOEHLER ${ }^{1}$ \\ USDA-ARS, Medical and Veterinary Entomology Research Laboratory, \\ P.O. Box 14565, Gainesville, Florida 32604
}

\begin{abstract}
J. Econ. Entomol. 85(4): 1209-1212 (1992)
ABSTRACT $\mathrm{LC}_{50} \mathrm{~s}$ and $\mathrm{LT}_{50} \mathrm{~s}$ of boric acid and polybor formulated in water and $10 \%$ sucrose were determined for 3- to 5-d-old adult house flies, Musca domestica (L.), of mixed sex. Differences between boric acid and polybor toxicities were significant in $10 \%$ sucrose, but not in water. However, borates formulated in water had significantly lower $\mathrm{LC}_{50} \mathrm{~s}$ than those formulated in $10 \%$ sucrose. Rate of kill for formulations in water was fairly uniform over time, whereas mortality from sucrose formulations was not observed until $17 \mathrm{~h}$ after treatment. Reasons for differences in the manifestation of mortality and possibilities for practical application are discussed.
\end{abstract}

KEY WORDS Insecta, Musca domestica, boric acid, polybor 3

BORIC ACID WAS the standard chemical used for control of larval muscoid fly populations in manure (Bishopp 1939, Midgley et al. 1943), sewage sludge (Olson \& Dahms 1945) and compost (Lal \& Srivastava 1950) until DDT and other chlorinated hydrocarbon pesticides became available (McGovran \& Piquett 1945). Polybor 3 (Polybor, disodium octaborate tetrahydrate) also provided excellent larval control when added to the diets of laying hens, but it produced adverse side effects in the hens-e.g., decreased egg production and premature molting (Burns et al. 1959, Sherwood 1959, Tower et al. 1960). In contrast, boric acid in a sugar-bait formulation proved relatively ineffective against adult house flies, Musca domestica L., compared with organophosphorus compounds (Langford et al. 1954).

On their Material Safety Data Sheets, U.S. Borax (Los Angeles, Calif.) considers boric acid and polybor to be relatively innocuous. Both have acute oral $L_{50} \mathrm{~s}$ (rats) $\geq 2 \mathrm{~g} / \mathrm{kg}$ and neither is classified as a carcinogen or skin irritant. Eye irritation, if it should occur with either compound, is slight and reversible. A positive aspect of polybor is that its solubility $(9.5 \%)$ is twice that of boric acid $(4.72 \%)$ at $20^{\circ} \mathrm{C}$.

The objective of our study was to compare the relative toxicities of liquid formulations of boric acid and polybor against house fly adults. These

This article reports the results of research only. Mention of a proprietary product or a pesticide does not constitute an endorsement or a recommendation for its use by USDA.

${ }^{1}$ Department of Entomology and Nematology, Institute of Food and Agricultural Sciences, University of Florida, Gainesville, Fla. 32611 . data will be useful for the formulation of liquid borate pesticides.

\section{Materials and Methods}

Boric acid and polybor were obtained from U.S. Borax and Chemical, Los Angeles, Calif. Aqueous solutions of both compounds were formulated in water and $10 \%$ sucrose on a wt/vol basis. Final treatment levels for boric acid and polybor in water and $10 \%$ sucrose were 0.15 , $0.24,0.325,0.41$, and $0.5 \%$; and $0.5,0.63,0.75$, 0.88 , and $1.0 \%$, respectively. Control treatments of water and $10 \%$ sucrose were used during each test. Treatments were administered in scintillation vials $(20 \mathrm{ml})$ fitted with a cotton wick. Care was taken to saturate the wicks completely with solution as they were forced into the vials. Dry food (powdered milk, granulated sugar, powdered egg yolk; $6: 6: 1$ ) was provided ad libitum in the caps of the scintillation vials.

Disposable test cages were made from 0.5-pint (236.6 ml) paper cans (The Fonda Group, Union, N.J.) by removing the bottoms and replacing them with disks of standard aluminum window screen. Cages were $\approx 3.4 \mathrm{~cm}$ high and $7.6 \mathrm{~cm}$ in diameter (inside measurements). After each test, the paper portion of the cages was discarded, but the screens were removed, cleaned, and reused.

Four cages (replications) of flies exposed to each borate treatment level and the appropriate untreated solvent (control) for $24 \mathrm{~h}$ constituted a test. Adult 3- to 5-d-old house flies (mixed-sex) from the USDA Gainesville multiresistant colony were used for all tests. Thirty-five flies were placed in each test cage while flies were chilled in a walk-in cooler at $\approx 1^{\circ} \mathrm{C}$. Flies were generally cooled for $<10 \mathrm{~min}$ and allowed to acclimate in 
Table 1. Responses of house flies to boric acid and polybor formulated in water and $10 \%$ sucrose (24-h mortality)

\begin{tabular}{lcccrrr}
\hline \multicolumn{1}{c}{ Treatment } & $n$ & LC $_{50}(\%)^{a}$ & $95 \%$ CI & LC $_{90}$ & 95\% CI \\
\hline Boric acid $\left(\mathrm{H}_{2} \mathrm{O}\right)$ & 431 & 0.37 & $0.33-0.42$ & 1.01 & $0.79-1.51$ \\
Polybor $\left(\mathrm{H}_{2} \mathrm{O}\right)$ & 425 & 0.44 & $0.41-0.50$ & 1.04 & $0.82-1.54$ & $3.94 \pm 0.38$ \\
Boric acid (10\% sucrose) & 193 & 0.88 & $0.82-0.95$ & 1.36 & $1.15-2.25$ & $6.76 \pm 1.81$ \\
Polybor (10\% sucrose) & 341 & 0.74 & $0.70-0.77$ & 1.13 & $1.04-1.28$ & $6.90 \pm 0.75$ \\
\hline
\end{tabular}

a Wtvol.

the treatment room for a minimum of $2 \mathrm{~h}$ before starting a test. The treatment room was maintained at $24^{\circ} \mathrm{C}$ and $65 \% \mathrm{RH}$.

About $15 \mathrm{~min}$ before treatments were introduced, overhead lights in the treatment room were extinguished and illumination was provided by two $15-\mathrm{W}$ ultraviolet fluorescent tubes on a fly trap. The trap was $\approx 20 \mathrm{~cm}$ in front of a closed-back kneehole desk and oriented so that most of the light was directed into the kneehole. In this near-dark condition $(<0.1 \mathrm{ft}-\mathrm{c})$, flies rested on the screened portion of the cages (oriented up), and became still.

A clean paper can lid was used to introduce treatments. One scintillation vial containing a boric acid or polybor formulation was placed horizontially in the lid along with a scintillation vial cap containing dry food. The screened portion of a test cage, with flies, was lifted from its lid and placed on the clean lid containing the treatment vial and food. This technique allowed us to begin the experiment with $100 \%$ live flies because any dead or dying flies were left behind on the old lids. Escapees totaled $<1 \%$.

After all treatments were in place, overhead lights were illuminated until the end of the test. Mortality in each cage was recorded 4, 17, 21, and $24 \mathrm{~h}$ after treatment. The criterion for death was complete cessation of movement. During mortality counts, vials and vial caps were carefully moved with a piece of wire inserted through the screen so that no dead flies would be overlooked. At the end of each test, all flies were killed and total flies per cage was recorded.

Two tests were performed using both borates and both solvents. The pooled data were subjected to probit analysis (SAS Institute 1985) for estimation of $\mathrm{LC}_{50}, \mathrm{LC}_{90}$, and $\mathrm{LT}_{50} \mathrm{~s} . \mathrm{LC}_{50}$ s and $\mathrm{LT}_{50} \mathrm{~s}$ with overlapping $95 \%$ confidence intervals were considered not significantly different. The $\mathrm{LC}_{50} \mathrm{~s}$ and $\mathrm{LC}_{90} \mathrm{~s}$ used for comparison were estimated from 24-h mortality data. We compared $\mathrm{LT}_{50} \mathrm{~s}$ from the highest dose of boric acid and polybor in each solvent.

\section{Results and Discussion}

$\mathrm{LC}_{50} \mathrm{~s} 24 \mathrm{~h}$ after treatment with boric acid and polybor in water $(0.37$ and $0.44 \%$, respectively) were not significantly different (Table 1). $\mathrm{LC}_{50} \mathrm{~s}$ $24 \mathrm{~h}$ after treatment with boric acid and polybor in $10 \%$ sucrose ( 0.88 and $0.74 \%$, respectively) were significantly different, although the slight numerical difference is probably of little practical importance. $\mathrm{LC}_{50} \mathrm{~s}$ of boric acid and polybor in water were significantly lower than $\mathrm{LC}_{50} \mathrm{~s}$ of boric acid and polybor in $10 \%$ sucrose. Slopes of probit lines for boric acid and polybor in $10 \%$ sucrose were steeper than those of boric acid and polybor in water (Fig. 1). Consequently, $\mathrm{LC}_{90}$ s of both compounds in both solvents-i.e., concentrations that may be in the range of practical application-were between 1.01 and $1.36 \%$ (Table 1).

$\mathrm{LT}_{50}$ estimates for $0.5 \%$ boric acid and polybor in water (22.3 and $19.7 \mathrm{~h}$, respectively) were not significantly different (Table 2). LT $_{50}$ estimates for $1.0 \%$ boric acid and polybor in $10 \%$ sucrose (21.0 and $18.1 \mathrm{~h}$, respectively) were significantly different (Table 2). However, the slight numerical difference is of little practical importance. Slopes of the probit lines for boric acid and polybor in $10 \%$ sucrose were steeper than those of boric acid and polybor in water (Table 2).

These results indicate no significant difference between the relative toxicities of boric acid and polybor in water and a significant but probably inconsequential numerical difference between the relative toxicities of boric acid and polybor in $10 \%$ sucrose (Table 1). Our data suggested that the difference in mortality was actually related to the solvents and not to the borates. Likewise, differences between slopes of probit lines for boron compounds formulated in water and $10 \%$ sucrose did not indicate that flies did not respond heterogeneously, but did suggest a difference in the rate of mortality. These differences in rates of mortality also were reflected by the respective slopes of the lethal time probit regressions for boron compounds formulated in water and $10 \%$ sucrose (Table 2).

Carbohydrate solutions-e.g., 10\% sucroseare shunted directly to the crop and released as needed in other muscoid diptera (Venkatesh \& Morrison 1980). Dietary carbohydrates were being supplied to our flies in the dry food, and energy utilization was limited by the small size of the test cages. Therefore, flies receiving the sucrose-base boron formulations were forced to consume additional carbohydrates from the only available water source. These carbohydrates 


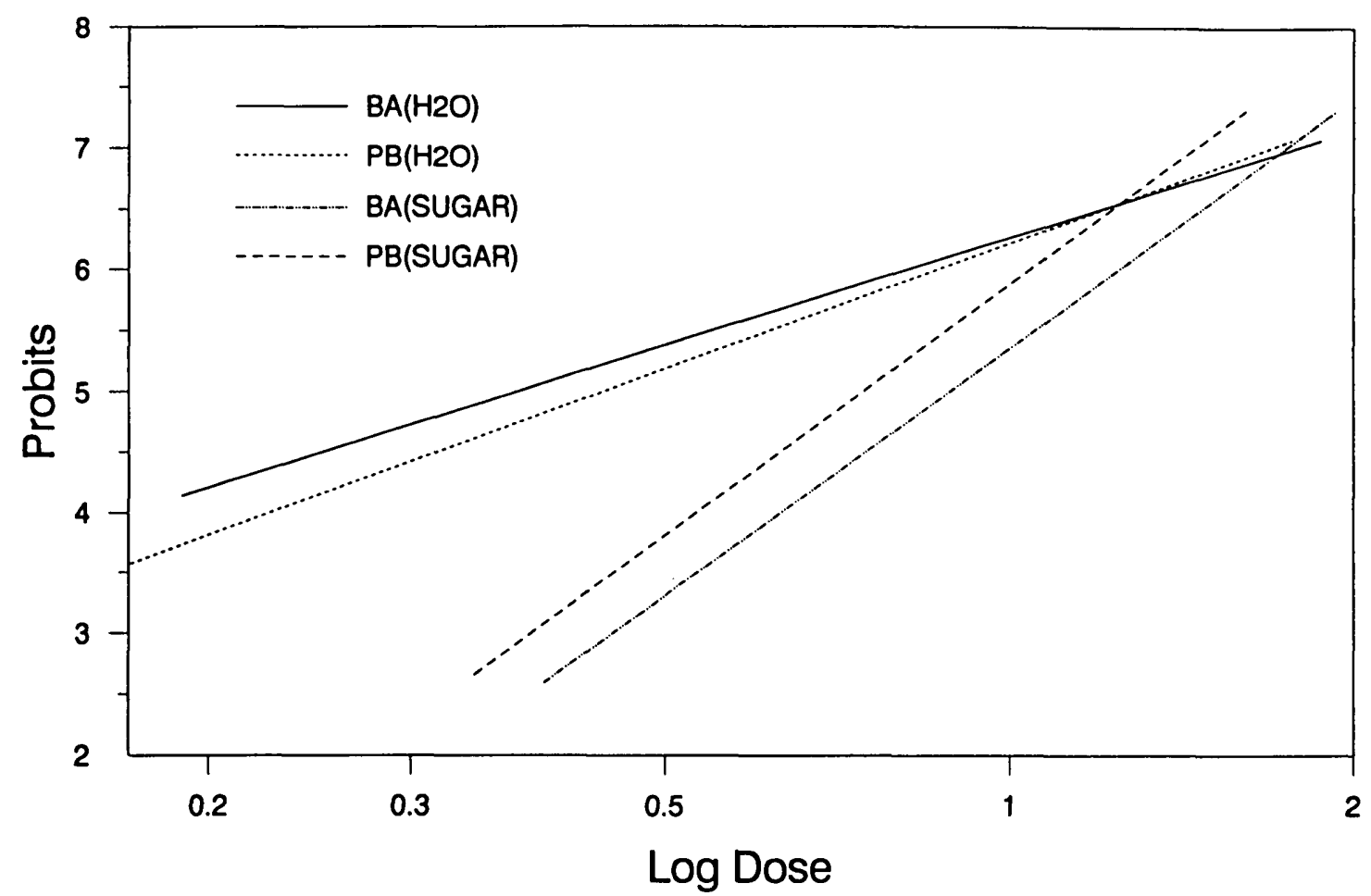

Fig. 1. Probit regressions for boric acid and polybor in water and $10 \%$ sucrose, respectively. BA, boric acid, $\mathrm{PB}$, polybor.

were probably being stored in the crop and released in small amounts over time. In contrast, water-base boron formulations were probably being taken directly into the midgut. This would explain why fly mortality from water-based boron formulations was observed throughout the 24 -h tests and fly mortality from $10 \%$ sucrosebased boron formulations was not observed until $17 \mathrm{~h}$ after treatment or later.

Because the relative toxicities of boric acid and polybor were similar numerically in the same solvents, more concentrated solutions of polybor in a sucrose base might prove worthwhile for practical use. In the field, sucrose should enhance the attractiveness of the solution because

Table 2. Responses of house flies to the most concentrated formulations of boric acid and polybor (in water and $10 \%$ sucrose) over time

\begin{tabular}{lcccc}
\hline \hline \multicolumn{1}{c}{ Formulation $^{a}$} & $n$ & $\mathrm{LT}_{50}(\mathrm{~h})$ & $95 \% \mathrm{CI}$ & Slope $\pm \mathrm{SE}$ \\
\hline $0.5 \%$ Boric acid $\left(\mathrm{H}_{2} \mathrm{O}\right)$ & 328 & 22.3 & $19.6-26.3$ & $2.75 \pm 0.41$ \\
$0.5 \%$ Polybor $\left(\mathrm{H}_{2} \mathrm{O}\right)$ & 408 & 19.7 & $17.7-22.2$ & $2.87 \pm 0.36$ \\
$1.0 \%$ Boric acid & & & & \\
$\begin{array}{l}(10 \% \text { sucrose }) \\
1.0 \% \text { Polybor }\end{array}$ & 177 & 21.0 & $19.6-22.8$ & $6.56 \pm 1.60$ \\
$(10 \%$ sucrose $)$ & 255 & 18.1 & $16.9-19.0$ & $8.68 \pm 1.40$ \\
\hline
\end{tabular}

${ }^{a} \mathrm{Wt} / \mathrm{vol}$. normal flight activity will require that more carbohydrate be used.

\section{Acknowledgment}

We thank F. Washington and G. Langley (USDAARS, Gainesville, Fla.), for their technical assistance in this study. This is Florida Agricultural Experiment Station Journal Series R-01687.

\section{References Cited}

Bishopp, F. C. 1939. Housefly control. USDA Leaflet No. 182. USDA, Washington, D.C.

Burns, E. C., B. A. Tower, F. L. Bonner \& H. C. Austin. 1959. Feeding polybor 3 for fly control under caged layers. I. Econ. Entomol. 52: 446-448.

Lal, B. N. \& S. B. Srivastava. 1950. Control of fly breeding in composting. Indian J. Agric. Sci. 20: 239-250.

Langford, G. S., W. T. Johnson \& W. C. Harding. 1954. Bait studies for fly control. J. Econ. Entomol. 47: 438-441.

McGovran, E. R. \& P. G. Piquett. 1945. Toxicity of benzene hexachloride to house fly larvae. J. Econ. Entomol. 38: 719.

Midgley, A. R., W. O. Mueller \& D. E. Dunklee. 1943. Borax and boric acid for control of flies in manure. J. Am. Soc. Agron. 35: 779-785.

Olson, T. A. \& R. G. Dahms. 1945. Control of house 
fly breeding in partially digested sewage sludge. J. Econ. Entomol. 38: 602-604.

SAS Institute. 1985. SAS user's guide: statistics. SAS Institute, Cary, N.C.

Sherwood, D. H. 1959. Effect of polybor 3 on egg production. Poult. Sci. 38: 491-493.

Tower, B. A., E. C. Burns, H. C. Austin \& F. L. Bonner. 1960. The performance of caged layers fed varying percentages of borax (polybor 3 ) in the ration. Poult. Sci. 39: 1190-1193.

Venkatesh, K. \& P. E. Morrison. 1980. Crop filling and crop emptying by the stable fly, Stomoxys calcitrans L. Can. J. Zool. 58: 57-63.

Received for publication 17 June 1991; accepted 7 February 1992. 